SECTION 4. Computer science, computer engineering and automation.

Shynar Abubakirovna Zhakipova

teacher

Kazakh National Medical University named after S. D.Asfendiyarov, Kazakhstan

shinar85@mail.ru

Aliya Sharizatovna Barakova

teacher

Kazakh National Medical University named after S. D.Asfendiyarov, Kazakhstan balia79@mail.ru

Sholpan Erlepesovna Zhysipbekova

senior teacher

Kazakh National Medical University named after S. D.Asfendiyarov, Kazakhstan sholpan_80aeka@mail.ru

\title{
FORMING WAYS OF INFORMATION WORLD VIEW OF INFORMATICS TEACHER
}

\begin{abstract}
Nowadays forming world view of physical person lies down to one of the basic on first necessities in education system. "Article of informatics is basis of It forming being counted, because it is possible to talk, that direction development all corresponds world to the achievements, to talk. In to connection from by it that to investigate forward put on our the work, investigates correspondingly to obligate philosophically, socially, pedagogical, psychologically and methodically to discuss world view, informative world view, found out informative world view concepts teacher of informatics theoretical bases.
\end{abstract}

Key words: information technologies, scientific research, teacher of computer science.

УДК 681.142.37+681.142.1+681.142.332

\section{ПУТИ ФОРМИРОВАНИЯ ИНФОРМАЦИОННОГО МИРОПОЗНАНИЯ ПРЕПОДАВАТЕЛЯ ИНФОРМАТИКИ}

\begin{abstract}
Аннотация: B данное время формирование личности является основным приоритетом в образовательной системе. Предмет информатики считается главным в формирований системь образования, потому что поток его развития соответствует с мировыми достижениями. Исходя из этого при исследований философских, соџиальньх, педагогических, психологических и методологических мировозрений выевляется понятие мировозрения информационной теории преподователя информатики.
\end{abstract}

Ключевые слова: информачиионные технологии, научные исследования, преподаватель информатики.

\section{ИНФОРМАТИКА ОҚЫТУШЫСЫНЫН АҚПАРАТТЫК ДҮНИЕТАНЫМЫН ҚАЛЫПТАСТЫРУ ЖОЛДАРЫ}

Аннотация: Қазіргі кезде жеке тұлганың дүниетанымын құальпптастыру - білім беру жүйесінде ең негізгі қ̧ажеттіліктердің біріне жатады. Оны қ̧алыптастырудың негізі болып «Информатика» пәні болып есептеледі, өйткені оның даму агымы бүкіл әлемдік жетістіктерге сәйкес келеді деп айтуга болады. Осыван орай зерттеу жұмысымызда алга құойван міндеттерге сәйкес философиялық, әлеуметтік, педагогикалық, психологиялық және ддістемелік зерттеулерді талдаулар арқыльы дүниетаным, ақпараттық дүниетаным, информатика оқыттушысының ақпараттық дүниетаным ұzыммдарыныңң теориялық негіздері айқ̧ындалады. 
Бұл зерттеуде модель ұғымын В.А.Штоффтың ізімен «зерттеу объектісін бейнелейтін және шығаратын оны объектіні үйренуде бізге жаңа ақпарат бере алатындай етіп, оның орнын басатын, ойша ұсынатын немесе материалды іске асыратын жүйесі» деп түсінеміз [1]. Модельдеу үдерісінде объекті жағынан зерттеу үшін қажет белгілері, фактілері, байланыстары, қарапайым және көрнекі форма түріндегі білімнің белгілері аясындағы талдау және қорытындылауға арналған ыңғайлы және түсінуге оңай қатынасы анықталады.

Модель кең мағынада - бұл кез-келген объектінің, үдерістің немесе құрылыстың бейнесі, аналогы (ойдағы немесе шартты - бейнесі, сипаты, сызбасы, графигі және т.б.), зерттелетін объект элементтерінің арасындағы қатынасы мен өзара байланыстарын, құрылымын, қасиеттерін бейнелейтін, оның «орынбасары», «ұсынушысы» ретінде қолданылатын және бізге қызық объект туралы ақпарат алуды жеңілденетін үдеріс. Модель түпнұсқаның құрылымын басқа жаққа аударады. Ол «құбылыстың жалпылама бейнесі, жалпылама практикалық тәжірибенің нәтижесі», объект туралы теориялық ұғымдар мен ол туралы білімнің қатынасын белгілеу болып табылады.

Дүниетаным құрылымын талдай отырып, біз болашақ информатика оқытушысының ақпараттық дүниетанымын қалыптастырудың моделін құрастырдық (1-сурет).

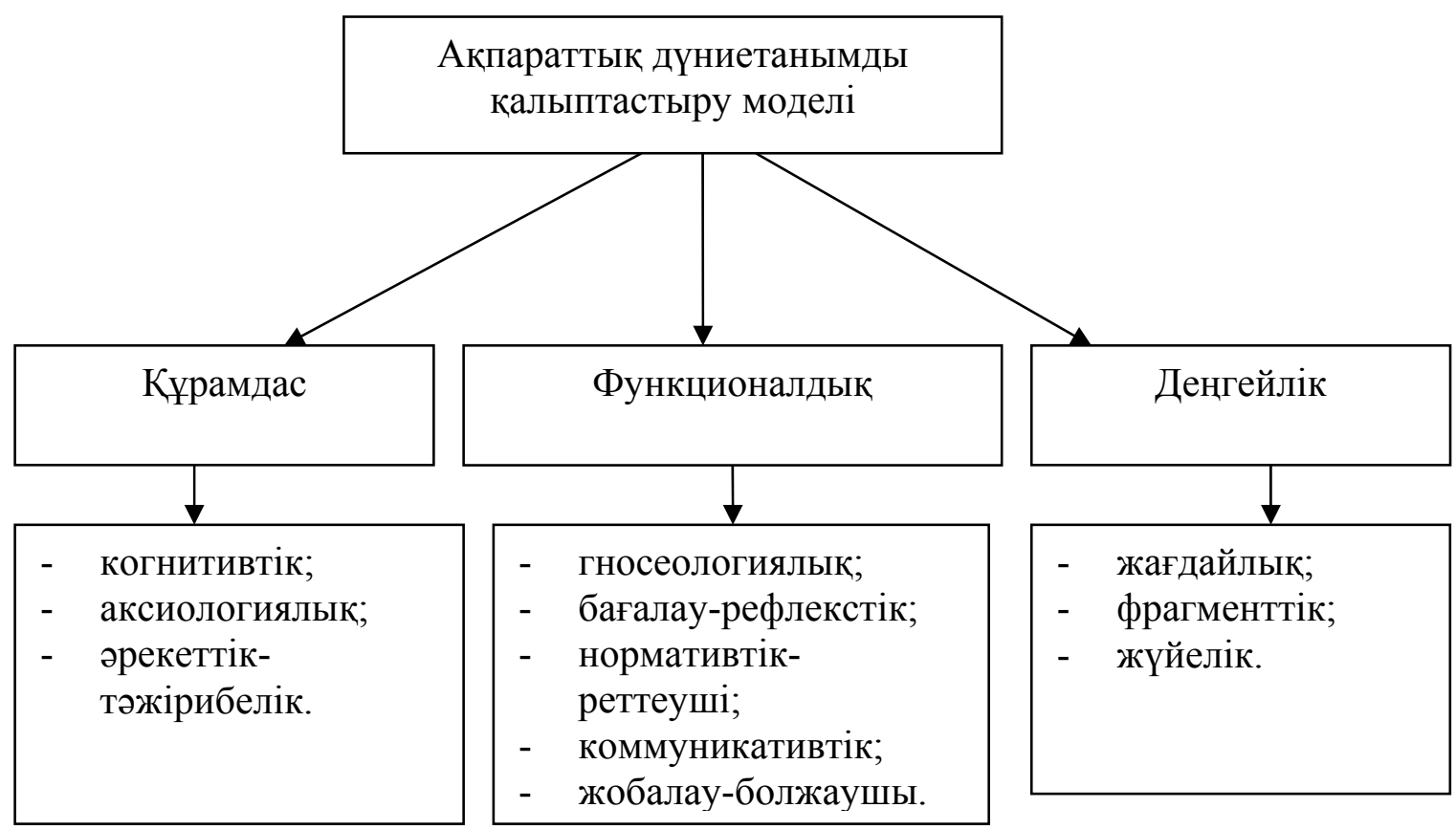

Сурет 1- Болашақ информатика оқытушысының ақпараттық дүниетанымын қалыптастырудың моделі

Кұрамдас модель.

Болашақ информатика оқытушысының ақпараттық дүниетанымының құрамдас моделінің негізгі құрамдас бөліктері - когнитивтік, аксиологиялық және әрекеттіктәжірибелік болып табылады.

Ақпараттық дүниетанымның когнитивтік құрамдас бөлігі негізгі ғылым ретінде информатика мен ақпараттық технологиялар төңірегіндегі білімді меңгерумен; табиғи, әлеуметтік, және техникалық (жүйелік-ақпараттық тәсіл) - жүйелердегі ақпараттық үдерістердің жалпы заңдылықтарын түсінумен; ақпараттық қоғам туралы толық ұғымдардың болуымен; ақпараттық технологияларды қолдануды іске асыратын оның әдіснамасын игерумен; коммуникация аясындағы жете білушілік - ақпараттық өзара әрекет пен өзара қатынаспен байланысты. 
Ақпараттық дүниетанымның аксилогиялық құрамдас бөлігі ақпараттық ортадағы жеке тұлғаның ақпараттық әрекетіндегі: құқықтық, этикалық және адамгершілік нормаларының құндылық-мағыналық маңыздылығымен; өзінің ақпараттық әрекетінің рефлекциясы және ақпараттық өзара әрекеттестік пен өзара қатынас тәртібінің өнегелі реттеуші тәжірибесімен; таным мақсаттарында, шығармашылық қызығушылығында және жеке тұлғалық іске асыруда ақпаратты таңдау, қолдану және құруымен; ақпараттық ортадағы - зорлық, зомбылық, өнегесіздік, талғамсыздық секілді кері әсерін сынтұрғысынан бағалауымен; меңгерген ақпараттық әрекеттің білімін, білігін, дағдысын қолдану жауапкершілігі және оларды қоғамда қолдануды іске асыруымен; жеке тұлғаның адам-машиналық жүйесіндегі дамуы мен денсаулығы, адам өмірінің құндылығы мен компьютерлік технологияларды қолдану шекарасын меңгеруімен; ақпараттық экология мәселелерін білу және оларды ақпараттық қоғам жағдайында жеңе білу қажеттілігімен байланысты.

Ақпараттық дүниетанымның әрекеттік-тәжірбиелік құрамдас бөлігі оның кәсіптік бағытымен: білім алушылар үшін ақпараттық дүниетанымды тасымалдаушысы ретінде информатика оқытушысы өзін санауымен; білім саласындағы ақпараттық үдерістерді талдау үшін жүйелі-ақпараттық тәсілді; информатика және ақпараттық технологиялар аясындағы дүниетанымның ерекшелігін меңгеруімен; оқушылардың ақпараттық дүниетанымын қалыптастыру қажеттілігімен; ақпараттық ортадағы оқушылардың болжайтын құндылық-мағыналық бағытын және оларды жеңе білу тәсілдерін ұсынумен; оқушылардың ақпараттық дүниетанымын қалыптастыру әдіснамасы және әдістемесін меңгеруімен байланысты.

\section{Функиионалдық модель.}

«Функция» сөзі латын тілінен «function» аударғанда «жөнелту, әрекет» деген мағынаны білдіреді. Функция - «басқадан тәуелді және сол басқаның өзгеру өлшемі бойынша өзгеретін құбылыс; міндеттілік, әрекет ортасы; белгілеу, рөл».

«Функция» термині үш мағынаны білдіреді: оның бірі «таза математикалық» (екі айнымалының арасындағы сәйкестік, тәуелді айнымалы), алға қалған екеуі педагогикалық және басқа ғылыми әдебиеттерде қолданылады: 1) міндеттілік, әрекет ортасы, белгілеу, алдын-ала белгілеу; 2) әрекетке қабілеттілік және ерекше (арнаулы) әрекет, қандай да бір құрылғының әрекеті, өсімдік немесе жануар организмінің, адамның мүшелері, ткандері және т.б.

Философиялық ғылымда «функция» берілген қатынас жүйесіндегі қандай да бір объектінің ішкі қасиеттерінің пайда болуымен сипатталады. Функцияны белсенділіктің, өмір әрекеті жүйесі мен оның құрауыштарының пайда болу тәсілдері, формасы тәрізді деп қарастырады. Функция жүйелері жүйедегі әрбір құрауыштарының бірін орындайтын толық функцияны анықтайды. Әдіснамалық және теория жүйесін талдау функция жүйелері мен оның құрауыштарының нәтижесінен шығады. Функция жүйесінде өзіне лайық заңдылықтарын ұсынатын оның тәртібі байқалады.

Көп зерттеулершілердің айтуынша функцияда оның құрылымына қарағанда тұтас табиғат, оның ерекшелігі мен маңызы бейнеленеді.

Болашақ информатика оқытушысының ақпараттық дүниетанымының негізгі функциялары адамның ақпараттық әрекеті ерекшелігінен, ақпараттық ортадағы оның өзара қатынасы мен өзара әрекетінің түрлілігінен пайда болады.

Біз болашақ информатика оқытушысының ақпараттық дүниетанымының келісідей функцияларын бөліп қарастырдық:

Гносеологиялық - жүйелі-ақпараттық тәсілмен қоршаған болмысты тануға, табиғат құбылыстарындағы, қоғамдағы адам өміріндегі ақпарат, ақпарат үдерістерінің анықталған рөлін меңгеруге бағытталған.

Бавалау-рефлекстік - ақпараттық ортадағы үйренетін және меңгерілетін рефлекстікмағыналық қатынасына құбылыс, үдеріс туралы жеке ойын білдіру, өзінің ақпараттық 
әрекетіндегі себеп, мағына, мақсат сапасы мен оның нәтижесі рефлекстерін қосуға бағытталған.

Нормативткі-реттеуші - ақпараттық ортадағы құқықтық, этикалық және адамгершілік нормаларын орындауға, ақпараттық әрекетінде оларды қолдану тәжірибесін, бостандық өлшемін, ондағы жауапкершілігі мен өзін шектеуіне бағытталған.

Коммуникативткі - «адам-адам» және «адам-компьютер-адам» (ақпараттық ортадағы біріккен әрекет тәжірибесі) диалог түрінің, ақпараттық өзара әрекет пен өзара қатынас рефлексиясының енуіне бағытталған.

Жобалау-болжаушы - эстетикалық, денсаулық, физикалық және жабдықталған қауіпсіздік үдерістерін іске асыру мақсатымен, ақпараттық әрекетін ұйымдастыру әдіснамасын өңдеуге, ұтқырлық, алғырлық пен дағдыланғыш секілді өзгермелі ақпараттық ортадағы шығармашылық қасиеттерін, өзінің ақпараттық әрекеттерінің мүмкіндіктерін болжауға бағытталған.

\section{Денгейлік модель.}

Болашақ информатика оқытушысының ақпараттық дүниетанымын біз динамикалық үдеріс ретінде қарастырамыз. Оның деңгейлік моделі негізінде жеке тұлғаның белгілі дәрежедегі ақпараттық дүниетанымының критерийі жатыр.

Педагогикалық зерттеулерде критерийлерді таңдау үдерістерін бір қатар зерттеулершілер қарастырған. Біз оларды келесі жүйелер түрінде ұсынамыз: объективті (зерттелетін белгіні мағыналы бағалауға көмектеседі, әртүрлі адамдар арасындағы таласты бағалауды жібермейді), адекватты (экспериментші не бағалағысы келеді, соны бағалайды, зерттейтін құбылыстарға қатынасы бойынша бейтараптылық, салыстырушылық, зерттелетін құбылыс немесе үдерісті салыстыруға көмектеседі), зерттелетін үдеріс немесе құбылыстардың маңызды көрсеткіштерінің мазмұны.

Информатика оқытушысының ақпараттық дүниетанымының мазмұны мен құрылымы тәжірибеде бақыланған, информатика оқытушысының ақпараттық дүниетанымын қалыптастырудың деңгейлік моделін құрдық. Ол ақпараттық дүниетанымын қалыптастырудың жавдайльқ, фрагменттік және жүйелік деңгейлерінен тұрады.

Болашақ информатика оқытушысының ақпараттық дүниетанымын қалыптастырудың жаддайлық денъгейі ақпараттық орта туралы күнделікті, үйреншікті ұғымдары басым болып көрінеді; ақпараттық әрекет бейне, үйлестік бойынша іске асады және репродуктивті түрде сиапатталған; танымда ақпараттық ортаның толық бейнесі жоқ. Қоршаған әрекетті тануда жүйелі-ақпараттық тәсіл белгілі немесе мүлдем белгілі емес. Ақпараттық білімдері жеңіл-желпі, оларды тәжірибеге, ақпараттық ортадағы күнделікті өмір әрекетіне ендіру таныс және жеке кезеңдерде болады. Ақпараттық ортадағы болашақ информатика оқытушысының бейімделуі ақпараттық ортадағы жалпы қабылданған бейнелер, мәдениет бейнелер, дәстүр тәртіптерінің рөлін меңгеру арқылы іске асырылады. Ақпараттық әрекеттің рефлексиясын, мағыналы шығармашылығының пайда болуын тұрақсыз және бәсең ретінде сипаттауға болады. Болашақ кәсіптік әрекет информатиканың дүниетаным қуатын іске асыруда меңгерілмейді.

Болашақ информатика оқытушысының ақпараттық дүниетанымын қалыптастырудың фрагменттік деңгейі оқытылатын информатика пәндерінің төңірегіндегі жеткілікті білімдерінің болуымен, басқа пәндерді окуда және күнделікті өмірде олардың рөлін меңгерумен сипатталады. Ақпараттық ортаның толық бейнесі әлі қалыптаспаған, ол оның жеке құрауыштарымен - компьютерлік коммуникация, техноорта (компьютер құрылғылары, желілер және т.б.) жергілікті мағлұматтармен шектелген. Оларды студенттер жүйелік-ақпараттық тәсілмен жаратылыстану ғылыми пәндерінің төңірегінде гуманитарлы пәндерге ауыстырмай-ақ (қоғам, мәдениет) меңгереді, бұл оларға қиындық туғызбайды. Студенттердің мотивациялық саласында маңызды орынды ақпараттық әрекеттегі олардың бірлесу сипатын анықтайтын қоршаған жағынан бағалау алады. Болашақ информатика 
оқытушысының ақпараттық дүниетанымын қалыптастырудағы бұл дейгей ақпараттық ортадағы өзін ұйымдастыру және өзін басқару тұрақты дағдыларымен сипатталады. Жүйелік деңгейде студенттер ақпараттық ортаның маңызы, құрылымы туралы терең және жүйелі білім алады. Олар жүйелі-ақпараттық тәсілмен жаратылыстану ғылымымен бірге, гуманитарлық ғылым аясында да меңгеріп, оны кең көлемдегі мәселелер мен міндеттерді шешу үшін қолдана алады. Студенттердің жеке салада ақпараттық кәсіптік әрекеттің білімін, білігі мен дағдысын қолдануға жауапкершілігі пайда болады. Студенттер жаңа ақпараттық шындыққа жылдам бейімделеді. Жүйелік деңгей ақпараттық ортадағы жеке тұлғаның қалыптасқан өзін меңгеруімен, өзін сай бағалауымен, жоғары деңгейде өзін ұйымдастыру және өзін басқаруымен сипатталады, қажет болжам, өзін талдау, ақпараттық әрекетті түзету іске асырылады, ақпараттық мәдениет аясындағы ары қарай өзін даму қажеттілігі белсенді болады. Болашақ кәсіптік әрекет информатиканың дүниетаным қуатын іске асыруда толық меңгеріледі, осы салада өзінің дамуына тұрақты бағытталған оқушылардың ақпараттық дүниетанымын қалыптастыру әдіснамасы мен әдістемесін меңгерудегі алынған бастапқы тәжірибесімен бекітіледі.

Жеке тұлғаны қалыптастырудың толық үдерісі, әрекеттестік және педагогикалық үдерісті ұйымдастыруға жеке бағытталған теориясының қағидаларына сүйеніп, біз когнитивтік-операчионалдық, құндыльққ-магынальққ жжәне кәсіптік-педагогикальљқ кезендерден тұратылн болашақ информатика оқылтушыссынылң ақупараттық дүниетанылыл қальлптастыру үдерісінің теориялыққ моделін құрастырдық. Олардың әрқайсысы ақпараттық дүниетанымның құрамдас бөліктерінің бірінде басым болады, әрбір кезеңде басымдылықты қалыптастыру қарастырылған және болашақ информатика оқытушысының ақпараттық дүниетанымын қалыптастырудың деңгейін жоғары деңгейге көтереді.

Бірінші кезең (когнитивтік-операционалдық) - «Информатика» курсы төнірегінде ақпараттық дүниетанымның когнитивтік құрамдас бөлігін қалыптастыру басым.

Eкінші кезең (құндылық-мағыналық) - «Компьютерлік желілер» курсы төңірегінде ақпараттық дүниетанымның аксиологиялық құрамдас бөлігін қалыптастырады.

Yшінші кезең (кәсіптік-педагогикалық) - «Информатиканы оқытудың теориясы мен әдістемесі» курсы төңірегінде ақпараттық дүниетанымның әрекеттік-тәжірибелік кұрамдас бөлігін қалыптастыру басым, сонымен қатар соңғы курстағы курстық жұмыстар мен студенттердің педагогикалық практикасына ерекше көңіл бөлінеді.

Болашақ информатика оқытушысының ақпараттық дүниетанымын қалыптастыру кезеңдерінің теориялық модельдерінің сипатталуы төмендегідей ұсынылды.

Бірінші - когнитивтік-операционалдық кезеннің басымдылық мақсаты фундаменталды ғылым ретінде информатика және ақпараттық технологиялар төңірегіндегі адам білімінің мәдениеттілік аясын меңгерумен, ақпараттық үдерістер жүйесінің табиғи, әлеуметтік және техникалық (жүйелі-ақпараттық тәсіл) секілді түрлерінің жалпы заңдылықтарын түсіндірумен; ақпараттық ортада ақпараттық әрекет тәжірибесімен және оның бағытын қамтамасыз ететін ақпараттық орта туралы түсініктің болуымен; ақпараттық технологияларды қолдануда оның әдіснамасын игерумен байланысты болашақ информатика мұғалімі дүниетанымының когнитивті құрамдас бөлігін қалыптастыру болып табылады.

Екінші - құндылыққ-мавыналық кезенңнің басымдылық мақсаты ақпараттық ортадағы жеке тұлғада әрекеттің құқықтық, этикалық және адамгершілік нормалары туралы түсініктері болуы; ақпараттық өзарақатынас және өзараәрекет жағдайында тәртібі мен жеке ақпараттық әрекеттің рефлексиясын реттейтін; ақпараттық әрекеттің қабылдаған білім, білік және дағдыларын қолдану жауапкершілігі: қоғам үшін қолдануда оның іске асуы; жеке тұлғаның ақпараттық экология мәселелерін және ақпараттық қоғам жағдайында оларды жүзеге асыру қажеттілігін меңгеруі; болашақ информатика оқытушысының 
ақпараттық дүниетанымының аксиологиялық құрамдас бөлігін қалыптастыру болып табылады.

Үшінші кәсіптік-педагогикальқ кезеңңнің негізгі мақсаты болашақ информатика оқытушысының кәсіби бағытымен: оқушылар үшін ақпараттық мәдениетті, ақпараттық дүниетанымды информатика мұғалімі тасымалдаушы екенін меңгерумен; білім саласындағы ақпараттық үдерісін талдауда жүйелі-ақпараттық тәсілді білумен, оқушылардың ақпараттық дүниетанымын қалыптастыру қажеттілігі мен адам білімі аясында информатика мен ақпараттық технологиялардың дүниетаным шамасын меңгерумен; «Информатиканы оқыту теориясы мен әдістемесі» курсы сонымен қатар студенттердің соңғы курстағы курстық жұмыстары мен педагогикалық практика төңірегінде жалпы білім беретін мектеп оқушыларының ақпараттық дүниетанымын қалыптастырудағы тәжірибенің қалыптасуымен, оқушылардың ақпараттық дүниетанымын қалыптастырудың әдіснамасы мен әдістемелік игеруімен байланысты оның ақпараттық дүниетанымының әрекеттік-тәжірибелік құрамдас бөлігін қалыптастыру болып табылады.

\section{References:}

1. Штофф В.А. Моделирование и философия. В.А. Штофф.-М.1996. 250 с.

2. Антонова С.Г. Информационное мировоззрение: К вопросу о сущности определения понятия / С.Г.Антонова // Проблемы информатизации культуры: сб.ст. - М., 1996.Вып.3. - С.23-28.

3. Караев Ж.А. Активизация познавательной деятельности учащихся в условиях применения компьютерной технологии обучения: автореф... докт. пед. наук. - Алматы, 1995.- 41c.

4. Медеуов Е.У. Основные направления подготовки специалистов в Республике Казахстан//Қазақтан жоғары мектебі. - Алматы, 1995. -№1. -С.15-18

5. ҚАЗАҚСТАН РЕСПУБЛИКАСЫНЫН МЕМЛЕКЕТТІК ЖАЛПЫҒА МІНДЕТТІ БІЛІМ БЕРУ СТАНДАРТЫ ҚР МЖМБС 3.08.261 - 2006 Ресми басылЫм, Астана.

6. Касьянов С.Н. Методическая система формирования информационного мировоззрения будущего учителя информатики. Дисс.на соиск.к.п.н., Москва, 2005г., с.174.

7. Кеңесбаев С. Болашақ педагогтарды дайындаудағы жаңа ақпараттық технологияны пайдалану. Информатика негіздері журналы, №5,2004,4-6б.

8. С.Ш.Тілеубай. Н.Т.Ошанова Ақпараттық ортадағы дүниетаным жағдайы - болашақ информатика мұғалімінің ақпараттық дүниетанымын қалыптастырудың негізгі құралы. Қазақстан Ғылымдар Академиясының Хабаршысы, №2, 2009ж.

9. Н.Т.Ошанова Білім беру жүйесіндегі коммуникациялық технологиялардың көмегімен оқушылардың дүниетанымдық көзқарасын қалыптастыру. Хабаршы Абай атындағы ҚазҰПУ, Алматы, №2(13), 2005ж.

10. Информатика мұғалімінің мамандығына қойылатын талаптар. Алматы, 1998ж.

11. Ж. Садыбекова Оку - тәрбие үрдісінде ақпараттық -коммуникациялық технологияны қолдану қажеттілігі «Информатика негіздері» 2008 ж.-№4 